\title{
WHO-undersøkelsen i Sør-Trøndelag: Parasuicidraten øker for unge kvinner
}

Ved Heidi H jelmeland

I regi av en stor europeisk W H 0 -undersøkelse har det pågått en registrering av parasuicid i SørTrøndelag fra slutten av 80-tallet. Registreringen viser at parasuicidraten for unge kvinner har økt kraftig fra midten av 90-tallet.

\section{Om undersøkelsen}

W HO/EU RO M ulticentre Study on

Suicidal Behaviour (Parasuicide) (BilleBrahe et al. 1995) har siden 1. januar 1989 pågått i en rekke regioner i Europa. Fra starten var 16 regioner fra 12 forskjellige land med, men de senere år er flere og flere kommet til, og ved siste opptelling var 27 regioner i 22 land aktivt med i undersøkelsen. Sør-Trøndelag fylke er den norske regionen og har vært med fra starten (dvs. registreringen her startet allerede tre måneder tidligere). U ndersøkelsen består av to deler, en registreringsdel og en intervjudel (EPSIS). Bare registreringsdelen i Sør-Trøndelag vil omtales her.

1. oktober 1988 ble det opprettet et registreringssystem beståen de av alle legesentere, privatpraktiserende leger, samt psykiatriske og somatiske sykehus i SørTrøndelag. A lle personer som var 15 àr og eldre og som kom i kontakt med helsevesenet etter et parasuicid, ble registrert på et skjema som hadde felles innhold for alle europeiske regioner. Skjemaet inneholdt en rekke variabler, først og fremst sosiodemografiske. I tillegg hadde Sør-Trøndelag en egen del som inneholdt mer kliniske/psykologiske variabler.

Skjemaene ble utfylt etter intervjuer med pasientene. H ele registreringsapparatet ble opprettholdt til utgangen av 1993.

Fra 1994 ble registreringen begrenset til de to største somatiske sykehusene, hvor allikevel de fleste pasientene ble henvist. Fra dette året har en derfor beregnet ratene basert på tallene fra de to sykehusene pluss en estimeringsfaktor basert på gjennomsnittlig andel pasienter registrert ved andre helseinstitusjoner i de foregående år.

Den norske delen av W HO -undersøkelsen er et samarbeidsprosjekt mellom ansatte ved Psykiatrisk poliklinikk Øya og Psykologisk og Psykiatrisk institutt ved N TN U. Datainnsamlingen har i hele prosjektperioden vært koordinert av poliklinikken (med psykiatrisk sykepleier Lisbeth 0 . Skjærvold som hovedansvarlig gjennom mesteparten av perioden).

I W HO -prosjektet brukes følgende definisjon av begrepet parasuicid:

\begin{abstract}
"Et forsøk på egenskade som ikke ender med døden. Individet har med vilje utført en non-habituell handling som uten hjelp eller intervensjon fra andre ville skadet ham eller henne, eller med vilje tatt et stoff i mengder utover det som er foreskrevet eller ellers er vanlig anerkjent terapeutisk dose, hvor målet er å oppnå forandringer som han eller hun ønsket å oppnå ved hjelp av de forventede fysiske konsekvenser"
\end{abstract}

(Platt et al. 1992)

D efinisjonen inkluderer med andre ord sel vpåførte skader og forgiftninger både med og uten dødsintensjon, men luker ut de habituelle selvskaderne.
A rlige personbaserte rater per 100000 innbyggere for perioden 1989-1999 er presentert i figur 1 og viser en nedgang fra slutten av 80-tallet totalt sett. Ved starten av vår registrering var raten i overkant av 200/ 100000 for kvinner og rundt 150/100 000 for menn. Raten for kvinner avtok i løpet av første halvdel av registreringsperioden, men har økt i løpet av siste halvdel. Raten for menn holdt seg relativt stabil til å begynne med, gikk så ned og ser ut til å ha stabilisert seg på et lavere nivå (i underkant av $100 / 100$ 000) i siste halvdel av registre ringsperioden, sammenlignet med første.

Parasuicidratene i aldersgrupper for 1999 er presentert i figur 2. D et har skjedd en forandring $\mathrm{i}$ aldersfordelingen for kvinner i løpet av registreringsperioden.

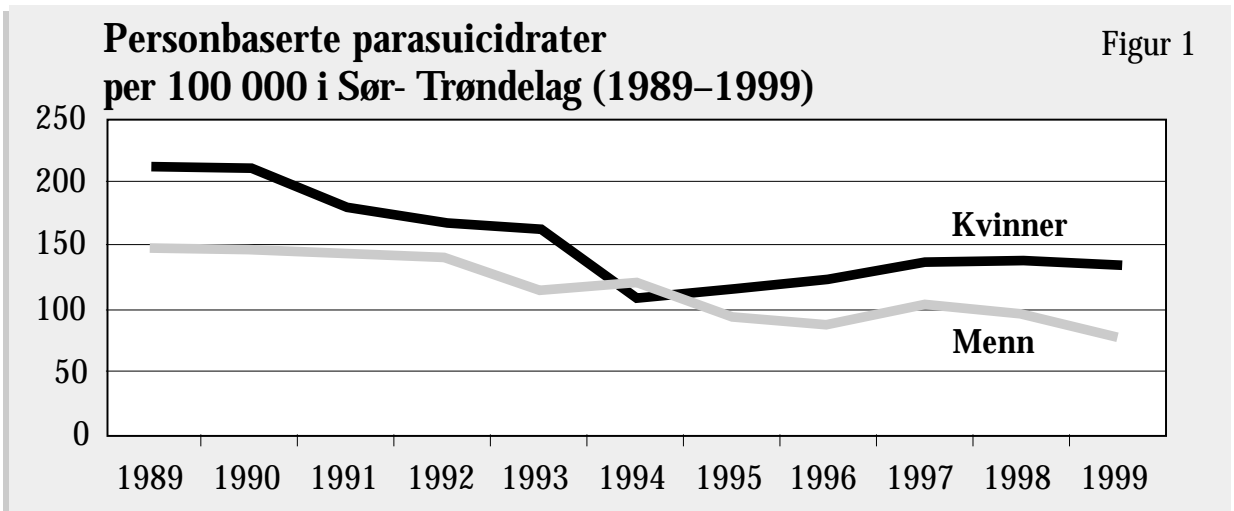

\section{Forekomst av parasuicid}

D et totale antallet parasuicidtilfeller registrert i Sør-Trøndelag i perioden fra 1. oktober 1988 til 31. desember 1999 var 3663. Det dreier seg om 2641 forskjellige personer, 1520 (58\%) kvinner og 1121 (42\%) menn. G jennomsnittsal deren var 35,9 for både kvinner (15-89 år) og menn (15-85 år).

$\mathrm{N}$ år det gjel der utvikling over tid, har en tidligere undersøkelse i området vist at raten for selvpåførte forgiftninger $i$ Trondheim økte kontinuerlig fra 1940 og opptil 1987, da raten var 287/100 000 for kvinner og 214/100 000 for menn (Rygnestad 1990; Rygnestad \& H auge 1991).
$M$ ens ratene i begynnelsen av perioden var høyest blant 20-49-åringene, har det skjedd en kraftig økning for unge kvinner de siste årene, slik at ratene nå er høyest blant de yngste (15-19 år). Denne økningen er vist i figur 3 . I begynnelsen av perioden fluktuerte raten for de yngste kvinnene rundt 250/100 000, før den begynte å avta ned mot 150/100 000. Fra 1995 har det imidlertid vært en nesten kontinuerlig økning, og raten for unge kvinner var 315/100 000 i 1999. Det har også vært en økende tendens i noen av de andre aldersgruppene, men ikke i samme grad som for de unge. Ser man på hele perioden, er ratene lavere i 1999 enn de var i 1989 for alle aldersgrupper unntatt for de yngste, 

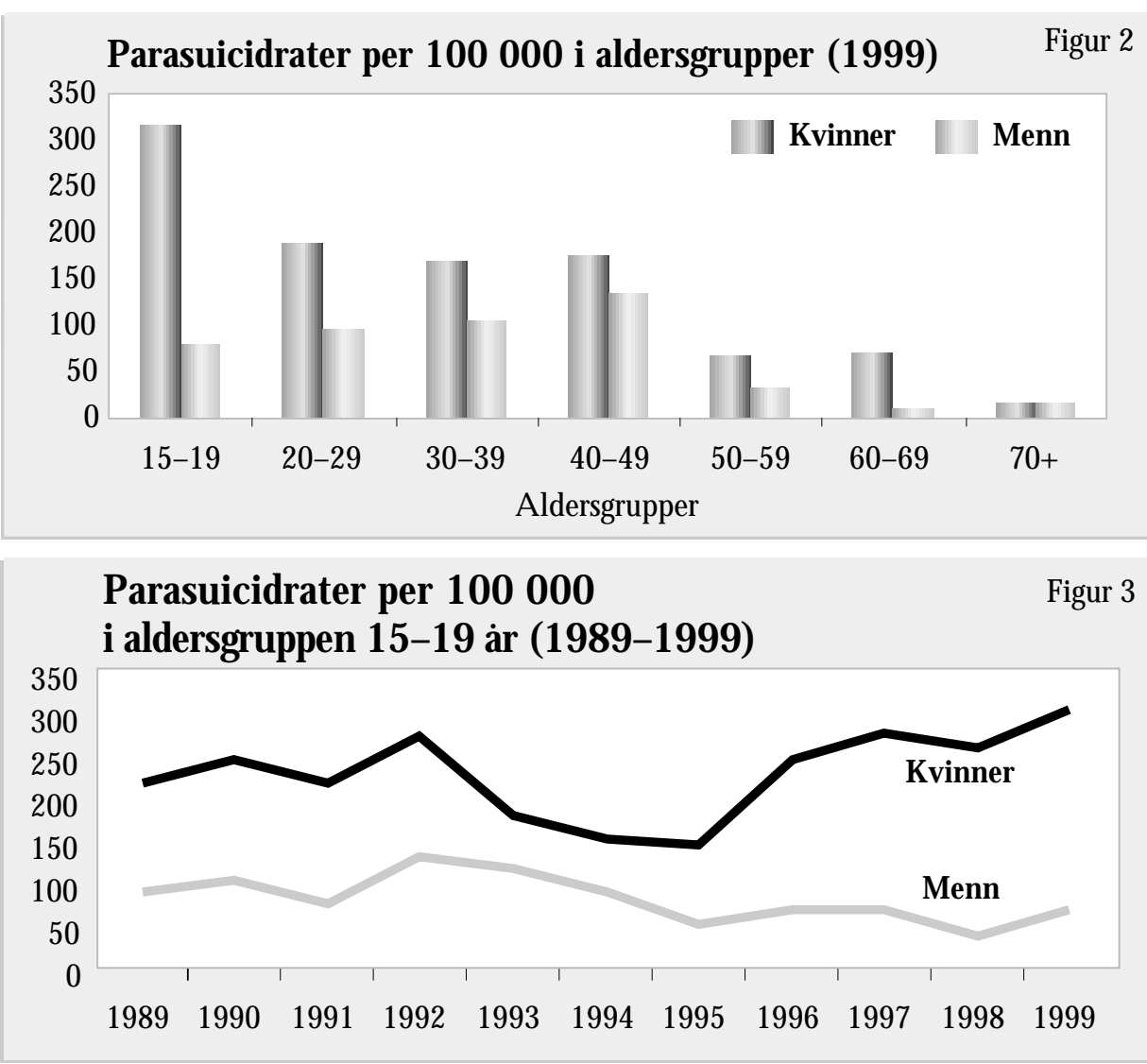

hvor de nå er høyere, og for kvinner over 60 år, hvor de har holdt seg relativt stabile gjennom hele perioden.

For menn har raten vært høyest $\mathrm{i}$ aldersgruppen 20-49 år gjennom hele perioden, men den totale raten har avtatt fra omkring 200-250/100 000 i 1989 til rundt 100/100 000 i 1999. Ratene i de andre aldersgruppene har fluktuert fra år til år, men i perioden sett under ett har ratene holdt seg relativt stabile. Det har altså ikke vært noen tilsvaren de økning for unge menn som den vi finner for unge kvinner.

$H$ vorvidt tallene for Sør-Trøndelag er representative for landet som helhet, er vanskelig å si. M ed unntak av Bærum kommune (Dieserud et al. 2000) har det ikke foregått noen tilsvarende registrering noe sted i landet i samme periode. Som fylke er imidlertid Sør-Trøndelag representativt for landet som sådan på variabler som har vist seg å kunne ha sammenheng med suicidal atferd. Dette gjelder f. eks befolkningstetthet, al dersstruktur, utdanningsnivà og sosioøkonomiske variabler. Sammenlignet med de andre europeiske regioner ligger Sør-Trøndelag omtrent på det europeiske gjennomsnittet.
$45 \%$ av parasuicidpasientene oppga å ha gjort ett eller flere parasuicid tidligere ( $47 \%$ av kvinnene og $43 \%$ av mennene). Å rlig prospektiv gjentaksrate har fluktuert rundt $20 \%$ uten noen klar øken de eller avtakende trend. Å rlig prospektiv gjentaksrate er definert som andel pasienter registrert for sitt første parasuicid innen et kalenderår, som gjorde et nytt parasuicid innen de neste 12 måneder ("moving window").

De aller fleste parasuicid dreier seg om sel vpåførte forgiftninger, mens $10 \%$ av kvinnene og $19 \%$ av mennene har brukt andre metoder. De fleste av de som har brukt andre metoder, har kuttet seg opp med skarpe gjenstander.

\section{Konklusjon}

Parasuicidratene ser generelt sett ut til å være på vei nedover, men økningen for unge kvinner er foruroligende. Satsingen på barn og unge i oppfølgingsprosjektet "Tiltak mot selvmord", som er en fortsettelse av $\mathrm{H}$ andlingsplan mot påkrevet. sel vmord, synes derfor å være høyst

\section{Referanser}

Bille-Brahe U, Schmidtke A, Kerkhof A JFM, De Leo D, Lönnqvist J, Platt S, Sampaio Faria J. Background and introduction to the W $\mathrm{H} \mathrm{O/}$ EU R O Multicentre Study on Parasuicide. Crisis 1995; 16(2): 72-78+84.

Dieserud G, Loeb $M \&$ Ekeberg $\varnothing$. Suicidal behavior in the municipality of $B$ ærum, $N$ orway: A 12-year prospective study on parasuicide and suicide. Suicide and Life-T hreatening Behavior 2000; 30 (1): 61-73.

Platt S, Bille-Brahe $U$, Kerkhof A, Schmidtke A, Bjerke $T, C$ repet $P$ et al. Parasuicide in Europe: The W H O/EU R O multicentre study on parasuicide. I. Introduction and preliminary analysis for 1989. A cta Psychiatrica Scandinavica 1992; 85: $97-104$.

Rygnestad T. D eliberate self-poisoning in Trondheim. Doktoravhandling. Trondheim: U niversitetet i Trondheim, 1990.

Rygnestad T \& H auge L. Epidemiological, social and psychiatric aspects in self-poisoned patients. Social Psychiatry and Psychiatric Epidemiology 1991; 26: 53-62.

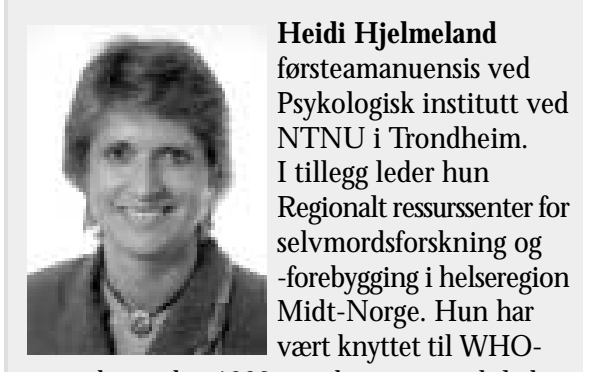

prosjektet siden 1992 og tok over prosjektlederansvaret for den norske delen av undersøkelsen etter professor Tore Bjerke i 1997.

\section{Referanser}

forts. fra s. 14

Grøholt B, Ekeberg O, W ichstrøm L, H aldorsen $T$. Young suicide attempters: a comparison between a clinical and an epidemiological sample. Journal of the A merican A cademy of C hild \& A dolescent Psychiatry 2000; 39 (7): 868-75.

H awton K, Fagg J, Platt S, H awkins M . Factors associated with suicide after parasuicide in young people. British M edical Journal 1993; 306: 16411644.

H awton K, Fagg J, Simkin S, Bale E, Bond A . D eliberate self-harm in adolescents in $\mathbf{0}$ xford, 1985-1995. Journal of A dolescence 2000; 23 (1): 47-55.

Rossow I, W ichstrøm L. Parasuicide and use of intoxicants among $N$ orwegian adolescents. Suicide and Life-threatening Behaviour 1994; 24: 174-83.

Schmidtke $A$ et al. A ttempted suicide in E urope: rates, trends and sociodemographic characteristics of suicide attempters during the period 1989 1992. Results of the WHO/EURO Multicentre Study on Parasuicide. A cta Psychiatrica Scandinavica 1996; 93 (5): 327-338. 